\title{
Municipal Responses to COVID-19: the case of library closures in New South Wales local government
}

\author{
Andrea Wallace 1 \\ Brian Dollery ${ }^{1}$ \\ 1 University of New England / Centre for Local Government, Armidale - Australia
}

In response to the COVID-19 pandemic, the New South Wales (NSW) government ordered the closure of all municipal libraries in order to limit the impact of the contagion. As a result, 372 public libraries in NSW ceased operation on the 23rd March 2020. While the closure of public libraries will undoubtedly contribute to restricting the spread of the coronavirus, given the pivotal role played by municipal libraries in local communities, as well as the special characteristics of library patrons, it will have other negative consequences. In this paper we consider the impact of the closure of municipal libraries in NSW from two perspectives: (a) its effect on the fiscal circumstances of local authorities and (b) its impact on the spread of the corona contagion as well as its broader effects on local community wellbeing. We conclude that rather than complete closure, partial constraints on library use should have been considered.

Keywords: COVID-19 pandemic; New South Wales; local government; public libraries.

\section{Respostas de municípios à COVID-19: 0 caso do fechamento das bibliotecas em Nova Gales do Sul}

Em resposta à pandemia da COVID-19, o governo de Nova Gales do Sul (NGS), na Austrália, ordenou o fechamento de todas as bibliotecas municipais com o objetivo de limitar os impactos da contaminação. Como resultado, 372 bibliotecas públicas pararam suas atividades no dia 23 de março de 2020. Embora o fechamento de bibliotecas públicas certamente contribui para restringir a propagação do vírus, deve-se considerar as consequências negativas dessa medida, dado o papel central desempenhado pelas bibliotecas municipais nas comunidades locais e as características particulares dos usuários. Este artigo discute os impactos do encerramento das atividades das bibliotecas em NGS através de duas perspectivas: (a) a partir do efeito da medida na situação fiscal dos municípios; e (b) o seu impacto em relação a propagação do vírus e seus efeitos mais amplos no bem-estar das comunidades locais. O estudo conclui que restrições parciais no acesso aos serviços deveriam ter sido consideradas como alternativa ao fechamento total das bibliotecas.

Palavras-chave: pandemia da COVID-19; Nova Gales do Sul; municípios; bibliotecas públicas.

\section{Respuestas municipales a la COVID-19: El caso del cierre de las bibliotecas de Nueva Gales del Sur}

En respuesta a la pandemia de COVID-19, el gobierno de Nueva Gales del Sur (NSW), Australia, ordenó el cierre de todas las bibliotecas municipales para limitar el impacto de la contaminación. Como resultado, 372 bibliotecas públicas de NSW cesaron sus operaciones el 23 de marzo del 2020. Aunque el cierre de las bibliotecas públicas indudablemente contribuirá a restringir la proliferación del coronavirus, se deben considerar las consecuencias negativas de dicha medida, dado el rol esencial de las bibliotecas municipales en las comunidades locales y las características particulares de sus usuarios. Este artículo discute los impactos del cese de actividades de las bibliotecas municipales de NSW desde dos perspectivas: (a) su efecto en la situación fiscal de los municipios y (b) su impacto en la proliferación del coronavirus, así como sus efectos más amplios en el bienestar de las comunidades locales. El estudio concluye que, en lugar de un cese total, se deberían haber considerado restricciones parciales al acceso las bibliotecas.

Palabras clave: pandemia de COVID-19; Nueva Gales del Sur; municipios; bibliotecas públicas. 


\section{ACKNOWLEDGMENTS}

The authors would like to thank the two anonymous reviewers for their helpful suggestions, and Dr. Emilio Morales and Professor Hugo Silvestre for translations.

\section{INTRODUCTION}

The sheer speed and global spread of the COVID-19 pandemic has stunned policymakers at all levels of government worldwide (Chinazzi et al., 2020; WHO, 2020). While it is far too earlier to assess the full impact of the pandemic on local government, the Australian Local Government Association (ALGA) has estimated that as many as 45,000 jobs could be lost across the seven Australian state and territory local government systems (Skatssoon, 2020). In New South Wales (NSW), Mayor Tony Bleasdale of Blacktown City Council - the largest council in NSW - has claimed Blacktown is losing $\$ 1.7$ million a week as a result of coronavirus restrictions, whilst warning councils may have difficulty maintaining basic services without financial support from higher tiers of government (Skatssoon, 2020a) ${ }^{1}$. Moreover, across NSW local authorities have been adversely affected in revenue terms by struggling residents' inability to pay property taxes, as well as various fees and charges.

Apart from petitioning higher tiers of government for emergency financial assistance, NSW local government is constrained by their inability to raise short term revenue. However, greater latitude for action exists in terms of the expenditure on services, because some non-essential services can be reduced or even halted in a relatively short time frame. Moreover, in some areas, including public libraries in the NSW local government system, local authorities have been instructed to cease service provision. Against this background, in this paper we examine the impact of closing municipal libraries in NSW in terms of its effects on local communities.

The paper is divided into four main parts. In section 2, we briefly describe NSW local government and its public library system. Section 3 offers some conceptual perspectives that guide the analysis in the paper. Section 4 outlines the rationale for closing the NSW municipal library system and then examines its likely impact on local communities. The paper ends in section 4 with some brief concluding remarks.

\section{NEW SOUTH WALES LOCAL GOVERNMENT LIBRARY SYSTEM}

Australia has a federal system of government comprised of a national government, seven state and territory governments, each with its own local government systems, except for the Australian Capital Territory (ACT), which has no local government system. In comparison with other developed multi-tiered governmental countries, the Australian federation is characterised by a comparatively high degree of vertical fiscal imbalance, with the federal government collecting much greater revenue that it directly expends. To address this characteristic of Australian federalism, a sophisticated system of intergovernmental grants has been developed, with the Commonwealth Grants Commission distributing billions of dollars in grants to state and territory governments, as well as local governments. The

${ }^{1}$ All pecuniary references in the paper refer to Australian dollars. 
disbursement of these grants is done in an apolitical manner using long established formulae. The net result is a relatively high degree of decentralisation compared with other comparable federal systems (Ivanya \& Shah, 2014).

In common with the other Australian state and territory local government systems, NSW local government has traditionally concentrated largely on "services to property" rather than on "services to people", many of which fall under the auspices of the NSW state government. NSW local authorities typically deal with waste collection and management, local bridges and roads, building approvals, health inspections, public recreational facilities and other related local services. Outside of the major metropolitan regions, many councils are also responsible for water provision and sewerage systems. Moreover, in remote areas, local councils sometimes provide services normally offered by the private sector, such as banking. A longstanding exception to this emphasis on services to property has been public libraries, which fall under NSW local government. Moreover, it should be noted that - over the past several decades - NSW local government has shifted steadily toward the provision of "services to people" (Dollery, Wallis \& Allan, 2006), especially in terms of aged care and child care.

In NSW, local authorities are financed by a mixture of property taxes, user fees and charges, fines, developer charges and intergovernmental grants from both the NSW government and the Australian federal government. NSW local government operates under the Local Government Act 1993 and councils are regulated by the NSW Office of Local Government.

In 2016, a municipal merger program reduced the number of local authorities from 152 entities to 128 municipalities. Some regions of NSW (Lord Howe Island and the Far West Division) - known as "unincorporated areas" - do not fall under any local authorities and are instead administered directly by the NSW Government.

As of May 2019, there were 372 public libraries in NSW (SLNSW, 2019), with each of the councils in the 128 Local Government Areas (LGA) of the state responsible for its operation. Municipal libraries in NSW are regulated by the State Library of NSW, which appoints an overarching committee - the Library Council of NSW - which is responsible for issuing guidelines for NSW public libraries under section 10(5) of the NSW Library Act 1939, no. 40 (NSW Legislation, 2020). All NSW councils have adopted the Library Act of 1939 and provide library services in accordance with the Act. Since all councils operate in accordance with the prescriptions of the Act, they are eligible for subsidies from the Library Council of NSW, as well as other avenues of potential funding, such as the NSW government annual funding program (SLNSW, 2019).

Public libraries are a longstanding and integral part of the social and economic fabric of many local communities across NSW. As shown in Table 1, public libraries are an especially popular source of recreation and education as demonstrated by attendance at library programs, and the number of registered public library members. Municipal libraries offer a variety of bespoke programs aimed at local communities, such as English language classes for non-English speakers, children's story-time programs, reading programs, and digital literacy. The libraries are also the employer for a significant number of full-time and part-time staff. It should be noted that over recent years library funding has been subject to austerity pressures (ALIA, 2016), including reduced funding from the NSW government, despite its manifold benefits to local communities, including unfettered access to information, as well as educational and social opportunities. 


\begin{tabular}{|c|c|c|c|}
\hline NSW Municipal Library Usage and Expenditure & $\begin{array}{c}\text { 2015/16 } \\
\text { Financial Year }\end{array}$ & $\begin{array}{c}\text { 2016/17 } \\
\text { Financial Year }\end{array}$ & $\begin{array}{c}\text { 2017/18 } \\
\text { Financial Year }\end{array}$ \\
\hline Physical visits to public libraries & 34.8 Million & 35 Million & 33.9 Million \\
\hline Loans of collection items & 42.1 Million & 41.25 Million & 40.2 Million \\
\hline Programs offered & 84,105 & 84,801 & 87,734 \\
\hline Attendance at programs & $1,574,896$ & $1,659,071$ & $1,751,651$ \\
\hline Local government expenditure on municipal libraries & $\$ 341,139,330$ & $\$ 373,931,210$ & $\$ 360,410,967$ \\
\hline NSW government expenditure on municipal libraries & $\$ 27,518,000$ & $\$ 28,322,000$ & $\$ 28,803,053$ \\
\hline Expenditure per capita & $\$ 48.42$ & $\$ 52.08$ & $\$ 49.53$ \\
\hline Items held by NSW public libraries & $13,149,354$ & $12,597,392$ & $13,123,512$ \\
\hline Registered public library members in NSW & $3,121,812$ & $3,203,005$ & $3,286,454$ \\
\hline Staff (part-time and full-time) employed in NSW municipal libraries & $2,292.68$ & $2,304.80$ & $2,319.43$ \\
\hline
\end{tabular}

Source: SLNSW $(2016,2017,2018)$.

Municipal libraries in NSW operate under the assumption that libraries exist to provide free access to ideas and information to all residents, coterminous with many public library systems worldwide (see, for example, ALIA, 2016). Municipal libraries adhere to the principle that all community members should be welcomed into a public library so they may be able to participate in, and contribute to society. It is widely accepted that people should be provided with library services in order to actively contribute to the economic and social wellbeing of themselves, their families and their local communities (ALIA, 2016).

Public libraries bestow a range of benefits on local communities. For instance, it has been estimated that each dollar expended on the public library system generates value of \$4.30AUD (McDougall \& Finney, 2018). Similarly, public libraries play a vital social role in alleviating loneliness and social isolation in local communities by providing a comfortable and safe space for patrons to interact with each other (Scott, 2011). In so doing, public libraries provide solace for many vulnerable members of a community (Dowdell \& Li Liew, 2019), thereby offering an affordable form of social welfare. Indeed, in Australia, some councils consider libraries to be at the forefront of providing social welfare; the Melbourne City Council, for instance, employs a specialised social worker to assist homeless library patrons with finding accommodation and other support (NSWPLA, 2019, p. 7).

Social cohesion is also a significant factor underwriting public library operations (see, for instance, Scott, 2011). As a consequence, public libraries are widely regarded by librarians and local public policymakers as the "community living rooms of towns" (NSWPLA, 2019, p. 4), where people may feel 
secure and enjoy social connection, whilst being able to participate in their community by accessing information (see Wang \& Lund, 2020).

As we shall argue, these considerations are significant when we consider the potential economic and sociological impact of public library closures across the entire NSW local government sector to limit the spread of COVID-19.

\section{CONCEPTUAL PERSPECTIVES}

In public administration the evaluation of the success, or otherwise, of public policies has spawned a voluminous literature (see, for example, McConnell, 2010; Bovens \& t'Hart, 2016; Moloney \& Moloney, 2020). In general three main approaches have been adopted: (a) a programmatic lens is used to assess specific claims made by the public policy proponents (Howlett, 2012); (b) a political lens is employed (Bovens \& t'Hart, 2016); and (c) a 'process' lens has also been used to measure the success of the stages through which a policy conception moves from its inception towards a fully implemented policy (Marsh \& McConnell, 2010). While these approaches all shed valuable light on public policy formulation, implementation and outcomes, they must be used exposte. Given that public policies adopted in NSW on COVID-19 are still evolving, in this paper we thus cannot adopt these theoretical lenses.

Instead we draw on the literature on loneliness and social isolation to inform our analysis of the impact of public library closures on community health across NSW local government. As we shall see in section 4 of the paper, the extant literature has two broad strands which can shed light in the present context. Firstly, it is important to consider the impact of heightened social isolation contingent upon public library closures upon the physical and mental wellbeing of socially isolated people (Malcolm, Frost \& Cowie, 2019). Secondly, the broader economic costs associated with loneliness and social isolation must be taken into account (Mihalopoulos et al., 2019).

\section{CRITICAL ANALYSIS OF THE NSW PUBLIC LIBRARY CLOSURES}

NSW municipal libraries were obliged to close on the $23^{\text {rd }}$ March 2020 in response to NSW Government policy guidelines recommending that citizens practice "social distancing" and avoid gathering in groups. It should be noted that the NSW Government acted in accordance with advice from both the Australian Government and the WHO. Moreover, it should be stressed that public library closures in NSW reflected similar public library closures in many other countries, including the United States (Wang \& Lund, 2020). The concept of "social distancing", as a way to prevent the spread of contagion, was promoted by the WHO as an established method of preventing the advance of highly contagious illnesses like COVID-19.

Social distancing, in Australia, was the concept where people, ideally, maintain a physical area of four-square metres between themselves and other people (Department of Health, Australian Government, 2020), and demonstrated to be an effective method of reducing viral transmission in the absence of suitable medications and vaccines (Glass, Glass, Beyeler \& Min, 2006). Social distancing was formally introduced across Australia by the federal government as a containment policy on $20^{\text {th }}$ March 2020, alongside the banning of non-essential indoor gatherings of more than one hundred people. 
Further efforts to contain the spread of the virus involved the closure of all indoor areas where people could gather in groups, such as gymnasiums, bars and restaurants, on the $23^{\text {rd }}$ March 2020. Municipal libraries fell into the same category and accordingly were closed in the same manner as bars and clubs. However, it is important note that in NSW many public facilities provided by local councils remained operational, including many municipal public parks, often with limited measure to ensure social distancing.

The rationale behind the closure of municipal libraries was thus similar to that of other spatially-limited areas where people could gather. It was argued that the unrestrained mass transmission of the COVID-19 virus could potentially overwhelm the Australian public health sector to the point that it would not be able to cope with the influx of patients. In addition, the health of library staff was an important consideration, particularly in light of how quickly and indiscriminately the corona virus can spread.

In NSW, the closure of municipal libraries was instituted in accordance with instructions from the State Library of NSW, which in turn worked with the Australian Library and Information Association (ALIA). Given the pivotal role that municipal libraries play in their local communities, as well as the demographic profile of library patrons, this decision was not taken lightly. Nonetheless, from the perspective of individual local authorities, the decision to close library doors was legally obligatory.

Any assessment of the impact of the NSW closure of public libraries as a consequence of the COVID-19 pandemic should be considered in at least two dimensions: (a) the effect on the fiscal circumstances of local authorities and (b) its impact on the spread of the corona contagion as well as its broader effects on local community wellbeing.

\subsection{Impact on fiscal circumstances of local councils}

Although it is far too early to measure the effects of the COVID-19 pandemic and the associated public policy responses to limit its spread, as we have seen, some NSW local authorities have already experienced sharp falls in revenue as newly unemployed homeowners and struggling businesses fail to pay property taxes, as well as other municipal fees and charges. In the short-run, there is little councils can do, except to appeal to higher tiers of government for remedial financial assistance to boost their flagging incomes. Moreover, they can also shut down non-essential local services, such as public libraries and recreational facilities, as a means of temporarily reducing expenditure.

In this respect the forced closure of the municipal library system in NSW will undoubtedly have a limited beneficial impact on the fiscal circumstances of local authorities. From Table 1, we can see that total expenditure on municipal libraries over the 2017/18 financial year was \$360,410,967 AUD (approximately $\$ 258,162,374$ USD in 2020). Although the temporary closure of municipal libraries will obviously generate only a small proportion of these total costs, this is nonetheless likely to be significant, even in the short-run. Cost savings can be expected from lower cleaning costs, less reliance on temporary casual workers and maintenance costs. 


\subsection{Impact on health of local communities}

As we have seen, the closure of municipal libraries represents part of a broader range of policies aimed at containing the COVID-19 pandemic in Australia. Given the public libraries and the programs they offer attract significant numbers of people, their continued normal operation poses dangers in terms of the spread of the contagion. By closing all public libraries in NSW, the NSW Government is thus contributing towards the battle against the pandemic. In this respect, we argue the closure of municipal libraries is partly justified.

However, once we take into consideration the socioeconomic, and other characteristics of a substantial proportion of library patrons, many of whom are from marginalised groups of people, the calculus on the overall health impact on local communities' changes. As we have seen, municipal libraries in NSW and elsewhere offer not only welcome opportunities for lonely and isolated people to interact socially, but also a range of community and welfare services to vulnerable groups, including access to information (see Wang \& Lund, 2020). Accordingly, the abrupt closure of the municipal library system in NSW has great potential to increase loneliness and social isolation in local communities. As we argued below, in line with the empirical literature on the impact of loneliness and social isolation, this will have ongoing costs in terms of the physical and mental wellbeing of the marginalised groups who patronise NSW public libraries.

While the terms loneliness and social isolation are often colloquially used as synonyms, in the scholarly literature they are treated different concepts (De Jong Gierveld, Van Tilburg \& Dykstra, 2006; Grenade \& Boldy, 2008). For instance, loneliness is customarily defined as an "unpleasant experience that occurs when a person's network of social relations is deficient in some important way, either quantitatively or qualitatively" (Perlman \& Peplau, 1981, p. 31). Under this definition, loneliness is an unwelcome negative subjective experience arising from an absence of sufficient interpersonal relationships (Malcolm et al., 2019). Thus De Jong Gierveld et al. (2006, p. 486) contend that "the opposite of loneliness" is when a person experiences "belongingness or embeddedness." By its nature, loneliness is thus quintessentially subjective.

By contrast, social isolation is conceived of as an objective state, in which a person has either limited interpersonal interaction, or an "absence of relationships with other people" (De Jong Gierveld et al., 2006 , p. 486). Given its objective nature, social isolation can be measured in various ways. For instance, it can be gauged by the size of a person's social network or by the frequency of social interactions (Grenade \& Boldy, 2008). Accordingly, an individual with "a very small number of meaningful ties" is typically defined as being socially isolated (De Jong Gierveld et al., 2006, p. 486).

Notwithstanding these differences between loneliness and social isolation, their impact on physical and mental wellbeing has attracted substantial attention in the scholarly literature (Grenade \& Boldy, 2008). The adverse effect effects of loneliness and social isolation are multifarious (see, for example, Cacioppo \& Cacioppo, 2018). For instance, loneliness has been associated with poorer physical and mental health outcomes (Australian Psychological Society, 2018) and even premature death (Holt-Lunstad, Smith, Baker, Harris \& Stephenson, 2015). In a similar vein, social isolation is linked to numerous adverse mental health conditions, like depression (Cacioppo, Hawkley \& Thistead, 2010) and the early onset of dementia (Wilson et al., 2007), as well as poor physical health, including heart disease (Sorkin, Rook \& Lu, 2002), cancer (Fox, Harper, Hyner \& Lyle, 1994) and infectious diseases (Pressman et al., 2005). 
Empirical studies have shown that the broader economic costs associated with loneliness and social isolation are substantial. For instance, Mihalopoulos et al. (2019) found that the majority of cost-of-illness studies on loneliness and social isolation "reported excess healthcare costs'. Similarly, total costs to employers, including the costs associated with lost productivity and absenteeism, have been found to be immense (New Economics Foundation, 2017).

\section{CONCLUSION}

In this paper we have considered the probable effects of the closure of the NSW municipal library system as part of a broader program to limit the spread of the COVID-19 pandemic. In the light of the negative financial impact of the pandemic and associated policy measures on NSW local authorities, especially in terms of municipal revenue, we argue that library closures will marginally reduce council outlays and thereby help to remedy income losses. However, from the perspective of local community health, we contend that whereas the total closure of the municipal library system will assist in restraining the spread of the pandemic, it will simultaneously have deleterious health effects, especially on the marginalised groups of people who use public libraries, by increasing loneliness and social isolation with their attendant health costs.

Given these considerations, we contend that the NSW Government should have chosen the 'middle road' option of keeping municipal libraries operational, but limiting the number of patrons at any time in order to ensure that approved social distance requirements could be met. Thus libraries could have continued operating, but with fewer patrons. This could have met the immediate requirements of the COVID-19 campaign, whilst simultaneously mitigating the adverse health impacts on the marginalised group of patrons for whom public libraries offer opportunities to alleviate loneliness and social isolation. Although this approach would have increased council expenditure, constraints on patron numbers would have meant fewer librarians were required and thus outlays would still have been below pre-COVID-19 levels.

The balance between offering libraries as a space for people to maintain social cohesion, against the fiscal and health costs of doing so are important to consider, and difficult to generalise whilst in the throws of a global pandemic. Fiscal, cultural, and other policy factors must be taken into consideration by policy-makers. However, and as one of the first COVID-19 policy studies to consider the pandemic's impact on public libraries, we suggest that there is an important, and complex, balance for policymakers. The jurisdiction-specific balance may vary from NSW but what does not change is the importance of this balance for all public library systems. 


\section{REFERENCES}

Australian Library and Information Association. (2016). Guidelines, Standards and Outcome Measures for Australian Public Libraries. Retrieved from https://read.alia.org.au/guidelines-standards-andoutcome-measures-australian-public-librariesjuly-2016

Australian Psychological Society. (2018). Australian loneliness report: A survey exploring the loneliness levels of Australians and the impact on their health and wellbeing. Melbourne, Australia: Author.

Bovens, M., \& 't Hart, P. (2016). Revisiting the Study of Policy Failures. Journal of European Public Policy, 23(5), 653-666.

Cacioppo, J. T., \& Cacioppo, S. (2017). Social relationships and health: The toxic effects of perceived social isolation. Social and Personality Psychology Compass, 8(2), 58-72.

Cacioppo, J. Y., Hawkley, L., \& Thistead, R. A. (2010). Perceived social isolation makes me sad: 5-year cross-lagged analyses of loneliness and depressive symptomatology in the Chicago Health, Aging, and Social Relations Study. Psychology and Aging, 25(2), 453-463.

Chinazzi, M., Davis, J. T., Ajelli, M., Gioannini, C., Litvinova, M. L. Merler, S., ... Vespignani, A. (2020). The effect of travel restrictions on the spread of the 2019 novel coronavirus (COVID-19) outbreak. Science, 368(6489), 395-400. Retrieved from https:// doi.org/10.1126/science.aba9757

De Jong Gierveld, J., Van Tilburg, T. G., \& Dykstra, P. A. (2006). Loneliness and social isolation. In A. Vangeliti, \& D. Perlman (Eds.), The Cambridge Handbook of Personal Relationships (pp. 485-500). Cambridge, UK: Cambridge University Press.

Department of Health, Australian Government. (2020). Coronavirus disease (COVID-19). Retrieved from https://www.health.gov.au/sites/default/ files/documents/2020/03/coronavirus-covid-19information-on-social-distancing_2.pdf

Dollery, B. E., Wallis, J., \& Allan, P. (2006). The debate that had to happen but never did: The changing role of Australian local government. Australian Journal of Political Science, 4(4), 553-567.
Dowdell, L., \& Li Liew, C. (2019, October). More than a shelter: Public Libraries and the information needs of people experiencing homelessness. Library \& Information Science Research, 41(4), 100984. Retrieved from https://doi.org/10.1016/j. lisr.2019.100984

Fox, C. M., Harper, A. P., Hyner, G. C., \& Lyle, R. M. (1994). Lonliness, emotional repressions, marital quality, an dmajor life events in women who develop breast cancer. Journal of Community Health, 19(6), 467-482.

Glass, R. J., Glass, L. M., Beyler, W. E., \& Min, H. J. (2006). Targeted social distancing designs for pandemic influenza. Emerging Infectious Diseases, 12(11), 1671-1681.

Grenade, L., \& Boldy, D. (2008). Social isolation and loneliness among older people: issues and future challenges in community and residential settings. Australian Health Review, 32(3), 468-478.

Holt-Lunstad, J., Smith, T. B., Baker, M., Harris, T., \& Stephenson, D. (2015). Loneliness and social isolation as risj ractors for mortality: A metaanalytical review. Perspectives on Psychological Science, 10(2), 227-237.

Howlett, M. (2012). The Lessons of Failure: Learning and Blame Avoidance in Public Policy-Making. International Political Science Review, 33(5), 539-555.

Ivanya, M., \& Shah, A. (2014). How Close if Your Government to its People? Worldwide Indicators on Localisation and Decentralisation. Economics, $8(3), 1-61$.

Legislation New South Wales. (2020). Library Act 1939, no. 40. Retrieved from https://www.legislation. nsw.gov.au/\#/view/act/1939/40

Malcolm, M., Frost, H., \& Cowie, J. (2019). Loneliness and social isolation causal association with health-related lifestyle risk in older adults: A systematic review and meta-analysis protocol. Systematic Review, 8(48), 1-8.

Marsh, D., \& McConnell, A. (2010). Towards a Framework for Establishing Policy Success. Public Administration, 88(2), 564-583.

McConnell, A. (2010). Policy Success, Policy Failure and Grey Areas In-Between. Journal of Public Policy, 30(3), 345-362. 
McDougall, A., \& Finney, B. (2018). Libraries Work! The Socio-economic value of public libraries to Victorians. Melbourne, Australia: SGS Economics and Planning.

Mihalopoulos, C., Le, L., Chatterton, M. L., Bucholc, J., Holt-Lunstad, J., Lim, M. H., ... Engel, L. (2019). The economic costs of loneliness: a review of costof-illness and economic evaluation studies. Social Psychiatry and Psychiatric Epidemiology, 55, 823-836. Retrieved from https://doi.org/10.1007/s00127-01901733-7

Moloney, K., \& Moloney, S. (2020). Australian Quarantine Policy: From Centralization to Coorindation with Mid-Pandemic COVID-19 Shifts. Public Administration Review, 80(4), 671-682.

New Economics Foundation. (2017). The cost of loneliness to UK employers. Manchester, UK: The Co-Op.

NSW Public Libraries Association. (2019). Renew Our Libraries! State of Our Libraries Report. Sydney, Australia: Author.

Perlman, D., \& Peplau, L. A. (1981). Toward a social psychology of loneliness. In S. Duck, \& R. Gilmour (Eds.), Personal Relationships in Disorder (pp. 31-56). London, UK: Academic Press.

Pressman, S. D., Cohen S., Miller G. E., Barkin, A., Rabin, B. S., \& Treanor, J. J. (2005). Loneliness, social network size, and immune response to influenza vaccination in college freshmen. Health Psychology, 24(3), 297-306.

Scott, R. (2011). The Role of Public Libraries in Community Building. Public Library Quarterly, 30(3), 191-227.

Skatssoon, J. (2020, April 05). 45000 council jobs in the balance as local government side lined.
Government News. Retrieved from https://www. governmentnews.com.au/45000-council-jobs-inthe-balance-as-local-govt-sidelined/

Skatssoon, J. (2020a, April 08). Sydney's biggest council bleeding $\$ 1.7 \mathrm{~m}$ a week. Government News. Retrieved from https://www.governmentnews. com.au/sydneys-biggest-council-bleeding-1-7ma-week/

Sorkin, D., Rook, K. S., \& Lu, J. L. (2002). Loneliness, lack of emotional support, lack of companionship, and the likelihood of having a heart condition in an elderly sample. Annals of Behavioral Medicine, 24(4), 290-298.

State Library New South Wales. (2016). Public Library Statistics 2015-16. Sydney, Australia: Author.

State Library New South Wales. (2017). Public Library Statistics 2016-17. Sydney, Australia: Author.

State Library New South Wales. (2018). Public Library Statistics 2017-18. Sydney, Australia: Author.

State Library New South Wales. (2019). Public Library Service. Retrieved from https://www.sl.nsw. gov.au/public-library-services/advice-and-bestpractice/public-library-statistics

Wang, T. and Lund, B. (2020). Announcement Information Provided by United States' Public Libraries during the 2020 COVID-19 Pandemic. Public Library Quarterly, 39(4), 283-294.

Wilson, R. S., Krueger, K. R., Arnold, S. E., Schneider, J. A., Kelly, J. F., Barnes, L. L., ... Bennett, D. (2007). Loneliness and risk of Alzheimer disease. Archives of General Psychiatry, 64(2), 234-240.

World Health Organization. (2020, April). Coronavirus disease 2019 (COVID-19) (Situation Report, 72). Geneva, Switzerland: Author. 


\section{Andrea Wallace}

https://orcid.org/0000-0002-4684-5039

Ph.D. in Public Administration and Lecturer in Management at the University of New England, Armidale, Australia.E-mail: awalla24@une.edu.au

\section{Brian Dollery}

https://orcid.org/0000-0003-2760-865X

Ph.D. in Economics; Professor of Economics at the University of New England, Armidale, Australia; Visiting Professor of Economics at the University of Yokohama, Japan. E-mail: bdollery@une.edu.au 